Original Article

\title{
Salivary Nitric Oxide Levels and Buccal Epithelial Cell DNA Damage in Oral Cancer - A Biochemical Study.
}

\author{
Fazil K.A. ${ }^{1}$, Renita Lorina Castelino ${ }^{2}$, Subhas G. Babu ${ }^{3}$, Suchetha Kumari ${ }^{4}$, Preethi Balan ${ }^{5}$, \\ Shishir Ram Shetty ${ }^{6}$, Medhini Madi ${ }^{7}$
}

${ }^{1,5}$ Lecturer, Department of Oral M edicine And Radiology, Sree Anjaneya Institute of Dental Sciences, Kerala University of Health Sciences, Calicut, ${ }^{2}$ Reader, ${ }^{3}$ Prof \& HOD, ' $L e c t u r e r$, Department of Oral Medicine And Radiology, A.B. Shetty Memorial Institute of Dental Sciences, Nitte University, ${ }^{4}$ Professor, Department of Biochemistry, K.S. Hedge Medical Academy, Nitte University, ${ }^{6} \mathrm{PhD}$, Assistant professor, Gulf Medical University, Ajman, UAE.

*Corresponding Author : Renita Lorina Castelino, Reader, Department of Oral Medicine and Radiology, A.B. Shetty M emorial Institute of Dental Sciences, Nitte University.

$\begin{array}{ll}\text { Received } & : 30.08 .2016 \\ \text { Review Completed } & : 06.01 .2017 \\ \text { Accepted } & : 08.01 .2017\end{array}$

Keywords : Oral cancer, DNA, comet assay

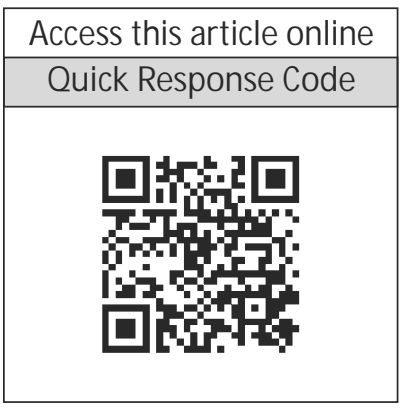

\begin{abstract}
Background : Cancer is the one of the common cause of mortality in developed and developing countries. Tobacco in any form is found to induce cancer formation. Oral cancer is a multistage process with progressive changes occurring in genetic and cellular morphology as the disease progresses from the normal to premalignant state and then to malignant state. Recent studies have emphasised that nitric oxide is a highly reactive molecule that interacts with DNA resulting in DNA damage.The objective of the present study was to evaluate the nitric oxide levels in the saliva and buccal epithelial cell DNA damage in patients with oral cancer.
\end{abstract}

\begin{abstract}
Material and methods : In this study nitric oxide levels in saliva and buccal epithelial cell DNA damage were estimated in 20 healthy individuals without oral lesions and 20 patients with oral cancer.

Results : The mean values of salivary nitric oxide levels were significantly greater in oral cancer patients $(126.2155 \mathrm{H}-2.7587)$ when compared to that of controls $(76.111+/ \mu \mathrm{M} / \mathrm{L})$. Similarly the extent of DNA damage was higher in subjects with oral cancer $(28.099+/-1.2696)$ than in controls $(9.15+-0.9131)$. Pearson's correlation between nitric oxide levels in saliva and extent of DNA damage were found to be moderately correlated in controlsr $=0.491(p \varangle 0.01)$ and in oral cancer patientsr $=0.428(p<0.01)$.
\end{abstract}

Conclusion : The results of present study illustrate an active involvement of nitric oxide which is derived from tobacco and its related products in the initiation of DNA damage and subsequent formation of oral cancer.

\section{Introduction}

Oral cancer accounts for 2-4\% of all cancer cases globally. More than $90 \%$ of the oral neoplasms are found to be oral squamous cell carcinomas (OSCC). ${ }^{1}$ It is ranked as the $12^{\text {th }}$ most common cancer worldwide ${ }^{2}$ and $90-95 \%$ of oral cancers in India are OSCC. ${ }^{3}$ The mortality rate due to oral cancer is predicted to rise from six lakh eighty thousand to 1-2 million. ${ }^{4}$

The diagnosis of OSCC is currently based mainly on thorough clinical examination and histopathological evaluation of the suspected lesion. ${ }^{5}$ In order to decrease the morbidity and mortality associated with the disease, development of certain non-invasive, safe, cost effective and reliable diagnostic markers is the need of the hour.

Nitric oxide (NO) molecule is a highly reactive oxygen free radical found in normal and cancerous tissues. ${ }^{6} \mathrm{NO}$ has pleiotropic features critical to various physiological and pathological processes including oral cancer pathogenesis. It is the product of the conversion of Larginine to L-citrulline and this conversion is catalyzed by nitric oxide synthase (NOS). Oxygen and other cofactors are essential in this reaction. ${ }^{8}$ Various cancer related events have been suggested to be modulated by nitric oxide. ${ }^{9}$ It participates in genotoxic events and causes DNA damage 
during the initial stages of cancer formation which includes inactivation of the DNA repair proteins, transitions and transversion of the bases. ${ }^{10,11}$ Hence the present study was undertaken to assess and correlate the nitric oxide levels in saliva and buccal epithelial cell DNA damage in healthy individuals and in patients with oral cancer.

\section{Material and Methods}

A randomized case control study was performed on subjects reporting to the Department of Oral M edicine and Radiology. The ethical clearance was obtained prior to conducting the study. The nature and purpose of the study was explained and informed consent was acquired from the subjects included in the study. A detailed case history was then recorded and a thorough oral examination was performed. A sample size of 40 subjects was divided in to 2 equal groups of 20 patients each.

Twenty healthy subjects who were controls (C) without any systemic and oral diseases and twenty subjects diagnosed with oral cancer who were considered as the study group (S) were included in the study. Strict inclusion and exclusion criteria were followed. Both the groups in the study included subjects between the ages of 20 to 60 years. Control group (C) included subjects without any history of oral and systemic diseases, who are not on long term medications and with no history of substance abuse.The study group (S) included subjects diagnosed histopathologically with oral cancer.The individuals with history of recent infection, subjects with systemic illness and subjects on any medication were omitted from the study.

\section{Method of collection of data}

The whole saliva was collected under resting conditions one hour after food intake. The patients were informed to accumulate saliva in their mouth and spit it into a graduated test tube for a period of ten minutes. After the collection, saliva was centrifuged at eight hundred rotation per minute at $48^{\circ} \mathrm{C}$ for ten minutes. The resultant supernatant was later subjected to biochemical analysis.

The subjects were also informed to rinse their mouth with water. The mucosal cells were then obtained by scrapings taken from the buccal mucosa using a slightly moistened metal spatula. The cells were immediately smeared on the microscopic slides which were later used for comet assay.

The estimation of nitric oxide levels in saliva was by done by Griess method ${ }^{[12]}$ based on the conversion of nitrate to nitrite with the help of an enzyme by colorimetric detection of nitrite. It is a diazotization reaction in which acetified nitric oxide produced a nitro sating agent. The nitro sating agent reacted with sulfanilic acid that resulted in the production of diazonium ion. The diazonium ion was coupled with N-(1-naphthyl) ethylenediamine. This resulted in the formation of the chromo phoricazo derivatives which absorbed light at 540 - 570 nanometer.The reagents used were sulphanilamide solution and $\mathrm{N}$-(1-naphthyl)-ethylene diamine (NED) dihydrochloride solution.

The preparation of Sulphanilamide solution was done by taking $0.5 \mathrm{~g}$ of sulphanilamide in $100 \mathrm{ml}$ of $20 \% \mathrm{v} / \mathrm{v} \mathrm{Hcl}(20 \mathrm{ml}$ $\mathrm{Hcl}+80 \mathrm{ml}$ distilled water $=100 \mathrm{ml} 20 \% \mathrm{v} / \mathrm{v} \mathrm{Hcl}$ ).

The preparation of $\mathrm{N}$-(1-naphthyl)-ethylene diamine dihydro chloride solution was done by taking $0.3 \mathrm{~g}$ of solid reagent (NED dihydro chloride) in $100 \mathrm{ml}$ of $1 \% \mathrm{v} / \mathrm{v} \mathrm{Hcl}(1 \mathrm{ml}$ of $\mathrm{Hcl}+99 \mathrm{ml}$ of distilled water $=100 \mathrm{ml}$ of $1 \% \mathrm{v} / \mathrm{v} \mathrm{Hcl}$. A standard nitric oxide solution was pipetted out into five different test tubes in the range 0.2 to $1 \mathrm{ml}$. By using distilled water, the volume of each test tube was made up to $1 \mathrm{ml} .1 \mathrm{ml}$ of the distilled water was taken in a separate test tube which served as blank. $1 \mathrm{ml}$ of the sulphanilamide solution and $1 \mathrm{ml}$ of the NED dihydro chloride solution was added to each test tube and mixed. All the test tubes were then incubated at room temperature for ten minutes and the absorbance was later read at 550 nanometer.The $100 \mu \mathrm{l}$ of saliva sample was taken in a test tube. The volume was prepared up to $1 \mathrm{ml}$ with $0.9 \mathrm{ml}$ of distilled water. $2 \mathrm{ml}$ of sulphanilamide solution was added and kept for five minutes. $2 \mathrm{ml}$ of NED dihydro chloride solution was added after five minutes. The absorbance was measured after ten minutes at $550 \mathrm{~nm}$. The concentration was then calculated from a calibration plot prepared from a series of standard 
nitrite. The final calculations were done and the concentration of nitric oxide in the sample of saliva was given in $\mu \mathrm{M} / \mathrm{l}$.

The Comet assay for detection of DNA damage ${ }^{[13]}$ was done by using a molten low-melting-point agarose to suspend the sample of cells at thirty seven degree Celsius. A microscopic slide was used to cast the mono suspension. A cover slip made of glass was held at an angulation to the microscopic slide. At the contact point between the coverslip and the slide the mono-suspension was applied. The agarose in its molten state was spread to form a layer as the coverslip was lowered onto the slide. The agarose was gelled at four degree Celsius after which the coverslip was detached. The agarose formed a matrix of carbohydrate fibers that encapsulated the cells, securing them in place. A solution was used to immerse the slides that caused the cells to lyse. The solution used for lysis in the comet assay comprised of a detergent like Triton X-100 and highly concentrated aqueous salt. Depending upon the type of damage the $\mathrm{pH}$ of the solution used for lysis was adjusted between neutral and alkaline $\mathrm{pH}$. The slides were later washed in distilled water after the lysis of cells for about one to two hours at $4^{\circ} \mathrm{C}$ to eliminate all salts. It was then dipped in an electrophoretic solution which was adjusted for its $\mathrm{pH}$ based on the type of damage that was being studied. The slides were left for approximately twenty minutes in the electrophoretic solution after which an electric field was applied. The double helix of the DNA was denatured to a single stranded nucleoid. An electric field of one volt per centimeter was applied for approximately 20 minutes. At the $\mathrm{pH}$ of 7 the slides were neutralized and stained with a fluorescent stain that was DNA-specific. It was then evaluated using a microscope attached to a charge-coupled device. This was then connected to a computer for image analysis using comet score software.

The data was then analysed with the help of SPSS version 17 software. ANOVA test was used for comparison between the groups, Chi- Square Test for the association of the age and gender between the groups. Pearson's correlation was used to correlate the levels of nitric oxide with the DNA damage in the groups.

\section{Results}

The Demographic data analysis of control group (C) was as follows - $60 \%$ of the subjects were within $21-30$ years, followed by $20 \%$ belonging to $31-40$ years, $15 \%$ belonging to $41-50$ years and $5 \%$ of the subjects were between $51-60$ years (TABLE 1). The mean age in this group was 30.2 years (TABLE 2).

Males comprised $75 \%$ of this group (15/20), while females formed the remaining $25 \%$ of the group (5/20) (TABLE 3).

The Demographic data analysis of study group (S) was as follows $-70 \%$ of the subjects in the study group were within $51-60$ years, followed by $25 \%$ belonging to $41-50$ years and $5 \%$ of the subjects were within 31-40 years. (TABLE 1). Mean age in this group is 54.3 years. (TABLE 2)The group comprised of $60 \%$ males $(12 / 20)$ and $40 \%$ females. (TABLE 3).

The mean salivary nitric oxide levels in control group (C) was $76.111+/-2.3346 \mu \mathrm{M} / \mathrm{L}$ whereas the mean salivary nitric oxide levels of study groups (S) was $126.2155 \mathrm{H}$ $2.7587 \mu \mathrm{M} / \mathrm{L}(\mathrm{TABLE} 4)$.

The mean buccal epithelial DNA damage in control group (C) was $9.15 \mathrm{H}-0.9131$ whereas the mean DNA damage of study group (S) was $28.099+1-1.2696$ respectively (TABLE 5).

Statistically highly significant difference was obtained when comparison of salivary nitric oxide levels between control group (C)and study group (S) group (TABLE6).

When the extent of DNA damage of control group (C) was compared to the extent of DNA damage in study group (S) the difference was highly significant ( $p \varangle 0.001$ ) (TABLE 7).

The correlation between nitric oxide levels and extent of DNA damage in control group had positive moderate correlation $(r=0.491)$ and was statistically significant $(P=0.03)$. (TABLE 8).

The correlation between nitric oxide levels and extent of 
DNA damage in study group had a positive moderate correlation ( $r=0.428)$ and was statistically significant $(p=0.02)$. (Table8).

Table 1 : Age Distribution within the Groups

\begin{tabular}{|c|c|c|c|}
\hline AGE GROUP & & CONTROL & S \\
\hline $21-30$ & COUNT & 12 & 0 \\
& $\%$ & $60 \%$ & $0 \%$ \\
\hline $31-40$ & COUNT & 4 & 1 \\
& $\%$ & $20 \%$ & $5 \%$ \\
\hline $41-50$ & COUNT & 3 & 5 \\
& $\%$ & $15 \%$ & $25 \%$ \\
\hline $51-60$ & COUNT & 1 & 14 \\
& $\%$ & $5 \%$ & $70 \%$ \\
\hline
\end{tabular}

Table 2 : M ean Age Distribution in Controls And Study Group

\begin{tabular}{|c|c|c|c|}
\hline & N & $\begin{array}{c}\text { Mean } \\
\text { (in years) }\end{array}$ & $\begin{array}{c}\text { Standard } \\
\text { Deviation }\end{array}$ \\
\hline Control Group & 20 & 30.2 & 10.035 \\
\hline Study group & 20 & 54.3 & 5.73 \\
\hline
\end{tabular}

Table 3 : Gender Distribution in Each Group

\begin{tabular}{|ll|c|c|}
\hline & & CONTROL & ORAL CANCER \\
\hline FEMALES & COUNT & 8 & 5 \\
& $\%$ WITHIN GROUPS & $40 \%$ & $25 \%$ \\
\hline MALES & COUNT & 12 & 15 \\
& $\%$ WITHIN GROUPS & $60 \%$ & $75 \%$ \\
\hline TOTAL & $\%$ WITHIN GROUPS & $100 \%$ & $100 \%$ \\
\hline
\end{tabular}

Table 4 : M ean Salivary Nitric Oxide Levels in Controls and Study Group

\begin{tabular}{|l|c|c|c|c|c|}
\hline & $\mathbf{N}$ & Mean & $\begin{array}{c}\text { Standard } \\
\text { Deviation }\end{array}$ & M inimum & M aximum \\
\hline Salivary Control & 20 & 76.11 & 2.3346 & 70.48 & 81.18 \\
\cline { 2 - 6 } Nitric Study & 20 & 126.2155 & 2.7587 & 119.79 & 132.63 \\
Oxide group & & & & & \\
level & & & & & \\
$(\mu \mathrm{M} / \mathrm{I})$ & & & & & \\
\hline
\end{tabular}

Table 5 : M ean DNA Damage in Controls and Study Group

\begin{tabular}{|l|c|c|c|c|c|}
\hline & N & Mean & $\begin{array}{c}\text { Std. } \\
\text { Deviation }\end{array}$ & M inimum & Maximum \\
\hline $\begin{array}{l}\text { Salivary Control } \\
\text { Nitric Study }\end{array}$ & 20 & 9.15 & 0.9132 & 7.15 & 11.15 \\
\cline { 2 - 6 } $\begin{array}{l}\text { Oxide group } \\
\text { level }\end{array}$ & 20 & 28.009 & 1.2696 & 25.37 & 30.62 \\
\hline
\end{tabular}

Table 6 : Comparison of Salivary Nitric Oxide Levels between Controls and Study Group

\begin{tabular}{|c|c|c|c|c|c|c|c|}
\hline & GROUPS & $\mathbf{N}$ & Mean & $\begin{array}{l}\text { Standard } \\
\text { Deviation }\end{array}$ & $\begin{array}{c}\text { Statistics/ } \\
\text { mean squares }\end{array}$ & $\begin{array}{l}\text { df2(Welch) } \\
\text { / F(Anova) }\end{array}$ & $p$ value \\
\hline SALIVARY & CONTROL & 20 & 76.111 & 2.334607 & 9212.296 & 1380.81 & $\$ 0.001$ \\
\hline $\begin{array}{l}\text { NITRIC } \\
\text { OXIDE }\end{array}$ & $\begin{array}{l}\text { ORAL } \\
\text { CANCER }\end{array}$ & 20 & 126.2155 & 2.758706 & & & $\angle 0.001$ \\
\hline
\end{tabular}

Table 7 : Comparison of DNA Damage between Controls and Study Group

\begin{tabular}{|l|l|c|c|c|c|c|c|}
\hline & N & Mean & $\begin{array}{c}\text { Standard } \\
\text { Deviation }\end{array}$ & $\begin{array}{c}\text { Statistics/ } \\
\text { mean squares }\end{array}$ & $\begin{array}{c}\text { df2(Welch) } \\
\text { / F(Anova) }\end{array}$ & p value \\
\hline $\begin{array}{l}\text { DNA } \\
\text { Damage }\end{array}$ & CONTROL & 20 & 9.15 & 0.913196 & 1294.586 & 1135.042 & $\underline{\underline{0.001}}$ \\
\cline { 2 - 8 } & $\begin{array}{l}\text { ORAL } \\
\text { CANCER }\end{array}$ & 20 & 28.099 & 1.269608 & & & $\underline{\underline{0.001}}$ \\
\hline
\end{tabular}

Table 8 : Correlation of the DNA Damage and the Nitric Oxide Levels in Controls and Study Group

\begin{tabular}{|c|c|c|c|c|}
\hline GROUPS & & & $\begin{array}{c}\text { SALIVARY } \\
\text { NITRIC OXIDE }\end{array}$ & $\begin{array}{c}\text { RESULT AND } \\
\text { INTERPRETATION }\end{array}$ \\
\hline \multirow[t]{5}{*}{ CONTROL } & \multirow[t]{5}{*}{ DNA Damage } & Pearson Correlation & .491 & \multirow{5}{*}{$\begin{array}{l}\text { POSITIVE M ODERATE } \\
\text { AND SIGNIFICANT } \\
\text { CORRELATION }\end{array}$} \\
\hline & & Sig. (2-tailed) & .030 & \\
\hline & & $\mathrm{N}$ & 20 & \\
\hline & & Sig. (2-tailed) & .040 & \\
\hline & & $\mathrm{N}$ & 20 & \\
\hline \multirow{3}{*}{$\begin{array}{l}\text { ORAL } \\
\text { CANCER }\end{array}$} & \multirow[t]{3}{*}{ DNA Damage } & Pearson Correlation & .428 & \multirow{3}{*}{$\begin{array}{l}\text { POSITIVE M ODERATE } \\
\text { AND SIGNIFICANT } \\
\text { CORRELATION }\end{array}$} \\
\hline & & Sig. (2-tailed) & .020 & \\
\hline & & $\mathrm{N}$ & 20 & \\
\hline
\end{tabular}




\section{Discussion}

Oral cancer has one of the greatest incidences in India comprising twelve percent of all malignancies in men and eight percent of all malignancies among women. ${ }^{14} \mathrm{The}$ difference in the occurrence of oral cancer between India and western countries is attributed to the dissimilarity in the practices of tobacco consumption. ${ }^{15}$ Usage of tobacco plays a significant part in etiology of oral cancer due to the increased production and generation of free radicals. ${ }^{16} \mathrm{The}$ ROS and nitric oxide are involved in the multistage process of carcinogenesis. Thus the free radicals act as initiators and promoters of oral cancer formation. ${ }^{17}$

The salivary nitric oxide levels in our study were elevated in subjects with oral cancer in comparison to healthy individuals which was in accordance with the study conducted by Bahar et $\mathrm{al}^{18}$. Their study showed that the composition of saliva in patients with oral squamous cell carcinoma was altered when compared with the healthy subjects by oxidative and nitrative stress. The nitric oxide levels in saliva could be enhanced due to the increased dietary nitric oxide from the tobacco and tobacco related products. In addition to this, nitric oxide levels are increased in oral cancer patients due to the over expression of inducible nitric oxide synthase ( iNOS). The likely sources of iNOS are malignant epithelial cells of oral cancer or inflammatory response induced by it. Patel JB et al conducted a study that showed increased plasma nitric oxide levels in patients with oral cancer. They assessed plasma levels of nitric oxide in healthy individuals without to bacco habits and patients with oral cancer. ${ }^{19}$ The studies stated above were conducted in serum which is an invasive method of collection. In our study we have taken saliva samples as it is easy to obtain and non invasive.

Nitric oxide mediates DNA damage through the formation of carcinogenic nitrosamines, generation of reactive

\section{References}

1. Markopoulos AK. Current aspects on oral squamous cell carcinoma. Open Dent J 2012; 6:126-30.

2. Singh MP, Kumar V, Agarwal A, Kumar R, Bhatt M LB, M isra S. Clinicoepidemiological study of oral squamous cell carcinoma: A tertiary care centre study in North India. J Oral Biol and Craniofac Res. 2016;6:31-4.

3. Jain V, Dharkar D, Nandin $\mathrm{H}$ et al. Various addiction patterns and nitrogen species and abnormalities in DNA repair mechanism. ${ }^{20}$

Saran R et $\mathrm{al}^{21}$, M anikantan P et $\mathrm{l}^{22}$, M ukkherjee S et $\mathrm{a}^{23}$ and by Jyoti $S$ et al $^{24}$ conducted studies on buccal epithelial cells to detect DNA damage using comet assay and found significant increase in the basal DNA damage. Similar approach was adopted by us in the present study which also showed similar results.

Our study attempted to evaluate DNA damage in relation to salivary nitric oxide levels in healthy controls and subjects with oral cancer. A significant positive correlation between nitric oxide levels in saliva and extent of DNA damage was observed in both the groups. Therefore, it can be stated that the increase in the levels of salivary nitric oxide appears to have marked effect on the DNA injury.The present study elucidated the source and the role of nitric oxide in the pathogenesis of oral cancer by causing significant DNA damage. Hence, it can be stated that saliva can be used as a diagnostic marker for early detection of oral cancer. In the present study exfoliative cytology was used for the collection of epithelial cells from buccal mucosa for DNA analysis. As the procedure is easy to perform with minimum requirements, this can be used for mass screening of oral cancer.

\section{Conclusion}

The study showed good results in terms of evaluating salivary nitric oxide and correlating it with buccal epithelial cell DNA damage. The promising results of the present suggest that nitric oxide released by tobacco and tobacco products are effective in inducing chromosomal damage that can be successfully detected by methods such as comet assay. Further studies are required to be conducted in larger sample sizeand compare the salivary nitric oxide levels and DNA damage in patients with potentially malignant disorders and oral cancer.

duration in head and neck carcinoma: an institutional experience from central India. Int J Health Sci Res. 2015; 5:130-35.

4. Bray, F, Ren, J-S, M asuyer, E, and Ferlay, J. Global estimates of cancer prevalence for 27 sites in the adult population in 2008. Int J Cancer. 2013; 132: 1133-1145.

5. Prasad G, McCullough M. Chemokines and cytokines as salivary 
biomarkers for the early diagnosis of oral cancer. Int J Dent 2013;2013:813756.

6. Palmer RM J, Ferrige AG, M oncada S: Nitric oxide release accounts for the biological activity of endothelial-derived relaxing factor. Nature 1987;327:524-526.

7. Mocellin S, Bronte V, and Nitti D Nitric oxide, a double edged sword in cancer biology: searching for therapeutic opportunities. M edl Res Rev 2007; 27:317-352.

8. Bentz, B. G., Simmons, R. L., Haines, G. K., 3rd, \&Radosevich, J. A. (). The yin and yang of nitric oxide: reflections on the physiology and pathophysiology of NO. Head Neck 2000;22: 71-83.

9. Ying $L$, Hofseth $L$ ): An emerging role for endothelial nitric oxide synthase in chronic inflammation and cancer. Cancer Res 2007, 67:1407-1410.

10. Jaiswal M., LaRusso, N. F., Burgart, L. J., \& Gores, G. J. Inflammatory cytokines induce DNA damage and inhibit DNA repair in cholangiocarcinoma cells by a nitric oxide-dependent mechanism. Cancer Res, 2000;60: 184-190.

11. Wink, D. A., Hines, H. B., Cheng, R. Y., Switzer, C. H., Flores-Santana et al. Nitric oxide and redox mechanisms in the immune response. J LeukocBiol 2011; 89:873-91.

12. Fiddler RN. Collaborative study of modified AOAC method of analysis for nitrite in meat and meat products. J Assoc Of Anal Chem. 1977;60:594-599

13. Olive PL, Banáth JP. The comet assay: a method to measure DNA damage in individual cells. Nature protocols-electronic edition-. 2006 Jan $1 ; 1(1): 23$.

14. Petersen EP et al. Oral cancer prevention \& control the approach of the world health organization. Oral Oncology 2009; 45:454-460.
15. Korde SD, Basak A, Chaudhary M, Goyal M, Vagga A. Enhanced nitrosative and oxidative stress with decreased total antioxidant capacity in patients with oral precancer and oral squamous cell carcinoma. Oncology 2011;80(5-6):382-9.

16. Nair U, Bartsch H, Nair J. Alert for an epidemic of oral cancer due to use of the betel quid substitutes gutkha and pan masala: a review of agents and causative mechanisms. M utagenesis 2004;19(4):251-62.

17. Ray G, Hussain SA. Oxidants , anti oxidants and carcinogenesis. Indian ExpBiol 2002;40:1213-32

18. Bahar G, Feinmesser R, Shpitzer T, Popovtze AR, Nagler RM. Salivary analysis in oral cancer patients DNA and protein oxidation, reactive nitrogen species, and antioxidant profile. Cancer 2007;109(1):54-9.

19. Patel JB, Shah FD, Shukla SN, Shah PM , Patel PS. Role of nitric oxide and antioxidant enzymes in the pathogenesis of oral cancer. JCRT 2009;5:247-53.

20. Li RH, Hotchkiss JH. Potential genotoxicity of chronically elevated nitric oxide: a review. M utat Res 1995;339:73-89.

21. Saran R, Tiwari RK ,ReddyP P Risk assessment of oral cancer in patients with pre-cancerous states of the oral cavity using micronucleus test and challenge assayj oral oncol 2008;44;354-360.

22. Manikantan P, Balachandar V, Sasikala K Mohanadevi S et al Lymphocyte DNA Damage in Chewing Tobacco Users ofCoimbatore, Tamilnadu, by Using Comet AssayJ Hum Ecol 2010; 31; 53-58.

23. M ukherjee S, Ray JG, Chaudhuri K. Evaluation of DNA damage in oral precancerous and squamous cell carcinoma patients by single cell gel electrophoresis Indian J Dent Res. 2011;22(5):735-6.

24. Jyoti $S$ et al Assessment of DNA damage by panmasala, gutkha chewing and smoking in buccal epithelial cells using alkaline single cell gel electrophoresis (SCGE). Egypt J M ed Hum Genet 2013; 1: 1-4. 